\title{
ALÉM DAS BOLEADEIRAS E DO CRUCIFIXO - UM COTEJO ENTRE CONTOS GAUCHESCOS E DUBLINENSES
}

\section{Sabrina Siqueira ${ }^{1}$}

Resumo: Espaços geograficamente distantes podem apresentar características similares ao longo do desenvolvimento de suas sociedades. A partir de uma breve contextualização histórica, este trabalho propõe identificar diferenças e semelhanças entre as obras Contos Gauchescos e Dublinenses, contemporâneas quanto à data de publicação. Guardadas as devidas proporções, como as diferenças socioculturais e as técnicas utilizadas pelos escritores Simões Lopes Neto e James Joyce, respectivamente, os dois livros são coleções de contos, abordam a questão da violência, mostram a aversão ao estrangeiro e remetem à importância da religiosidade nas localidades em que transcorrem as narrativas.

Palavras-chave: conto; literatura comparada; Contos Gauchescos; Dublinenses.

Abstract: Geographically distant places can present similar features throughout the development of their societies. Starting from a brief historical contextualization, this work proposes identify differences and similarities between the works Contos Gauchescos and Dubliners, contemporary as the publication date. Mutatis mutandis, as the social-cultural differences and the techniques used by Simões Lopes Neto and James Joyce, respectively, both books are short stories colections, address to the question of violence, show foreign aversion and point to the importance of religiosity in the locations where the narratives flow.

Key-words: short story, comparison literature, Contos Gauchescos, Dubliners.

\footnotetext{
${ }^{1}$ Mestranda em Letras - Estudos Literários pela UFSM. Integrante da linha de pesquisa Literatura, Comparatismo e Crítica Social e do Grupo de Estudos Literatura e Autoritarismo. E-mail: sabrinasiqueir@yahoo.com.br
} 
Simões Lopes Neto e James Joyce pertenceram a sistemas literários distintos. O escritor gaúcho é geralmente associado ao regionalismo, que se manifestaria em sua obra marcadamente pelo emprego do linguajar sul-riograndense, além das temáticas e da ambientação. Enquanto James Joyce dificilmente seria classificado como um escritor regionalista. No entanto, 0 conjunto de sua obra é marcado pela presença da terra natal, a Irlanda, e em especial a capital, Dublin, que é cenário de romances como Retrato do artista quando jovem e do clássico Ulisses. Os livros deles analisados neste trabalho são contemporâneos: Contos Gauchescos foi publicado em 1912 e Dublinenses em 1914, e iluminam o lugar de origem de seus autores já no título.

Partindo-se dessa contemporaneidade entre as obras, consegue-se observar as diferenças culturais desses dois locais em diferentes estágios de evolução urbana, histórica, cultural e social - Rio Grande do Sul e Irlanda. Para tanto, serão utilizadas como fio condutor as diferentes abordagens da violência nas duas sociedades, bem como questões de religiosidade e o comportamento adotado frente ao que é estrangeiro. Sobre a possibilidade de cotejo entre obras literárias, Tania Carvalhal explica que "comparar não é justapor ou sobrepor, mas é, sobretudo, investigar, indagar, formular questões que nos digam não somente sobre os elementos em jogo (o literário, o artístico), mas sobre o que os ampara (o cultural, por extensão, o social)" (Carvalhal, 1991, p. 11).

Além da presença da terra natal dos escritores e da contemporaneidade da primeira publicação, os títulos classificam-se no gênero conto, sendo que estes podem ser lidos tanto de forma independentes quanto em uma suposição de vínculos, conforme será analisado mais à frente. Os dois livros contam episódios cotidianos sobre determinado povo, gaúchos e dublinenses, mas 0 fazem como metonímia da condição humana universal, abordando, em algumas histórias, questões comportamentais.

Considerando o campo de estudos da literatura comparada como espaço privilegiado para pesquisar as inter-relações em variadas formas de expressão, e a ênfase da disciplina em aproximar alteridades, observa-se que 
as obras analisadas oferecem características importantes que permitem interpretar o local e o universal. Para Tania Franco Carvalhal é a diferença que permite a inserção no universal: "comparar é contrastar" (1992, p. 77). Já Henry Remak atenta para o fato de que "um estudo de literatura comparada não tem que ser comparativo a cada página ou a cada capítulo, mas o propósito, a ênfase e a execução globais devem ser comparativos" (In: Carvalhal e Coutinho, 1994, p. 185). Algumas vezes, ao se estudar profundamente uma característica local em determinada obra literária, encontra-se um traço marcadamente universal. Ao pensar sobre o conceito da Weltliteratur, ou literatura mundial Eloá Heise considera que

\begin{abstract}
entender uma manifestação literária como Weltliteratur não significa abrir mão de sua especificidade como literatura nacional; significa, antes de tudo, um mergulho no nacional até que se encontre o que há nele de universal. Uma obra de literatura universal precisaria, portanto, ter uma particularidade própria. Só assim daria expressão, de forma representativa, ao caráter desse povo. Esse caráter próprio, por sua vez, apresenta-se como uma manifestação especial da humanidade como um todo [...] é a partir do local que se chega ao universal, resgatando o peculiar é que se alcança o geral (HEISE, 2007, p. 49).
\end{abstract}

A autora destaca a vocação para o esclarecimento do que é universal pela Weltliteratur, a partir da análise do que é nacional, e vice-versa:

O conceito Weltliteratur não se concretiza, pois, apenas na direção de buscar no nacional o que há de universal, mas também no sentido inverso: em meio ao universal, resgatar o que existe de nacional. Identificar-se com uma cultura estrangeira é reconhecer nela o que há de universalmente humano, como reflexo de algo peculiar a sua própria cultura. (HEISE, 2007, p. 51)

O cotejo entre as obras Contos Gauchescos e Dublinenses visa situá-las histórica e culturalmente uma em relação à outra, iluminando pontos de convergência e de semelhança. As narrativas transparecem a crítica social feita pelos escritores. Entre as diferenças, podemos apontar o ambiente em que as narrativas tomam forma. Em Contos Gauchescos prevalece o cenário rural, com cidades ainda restritas à categoria de povoados em formação, enquanto que Dublinenses fala sobre indivíduos que transitam em uma capital europeia bem estruturada do ponto de vista de comércio, rede de transportes e organização urbana. A violência, fator intrínseco aos contos dos dois sistemas 
literários, é explorada de formas distintas e é apresentada em ambos "como construção material e histórica. Não se trata de uma manifestação que seja entendida fora de referências no tempo e no espaço" (Ginzburg, 2012, p. 8).

Sérgio Luiz Prado Bellei, pensando a forma diferenciada como os teóricos Edward Said e Fredric Jameson denunciaram "a cultura 'civilizatória' da violência" (1997, p. 12), pondera que, para esses autores, "o texto literário ou cultural deve ser pensado como uma prática discursiva em íntimo relacionamento com outras práticas discursivas existentes na estrutura social e histórica" (Bellei, 1997, p.12). As circunstâncias históricas que envolvem as obras analisadas em uma investigação comparatista são fundamentais. Faremos um breve apanhado da História que antecedeu o período de escritura dos contos como tentativa de localizar a influência desses acontecimentos reais nas narrativas e de justificar as suas abordagens da violência.

O Rio Grande do Sul vivenciou diversas batalhas e revoluções ao longo de sua formação. Estado fronteiriço com outros países, esteve sob a disputa de portugueses e espanhóis. Mesmo depois da independência do Brasil, foi cenário de revoltas entre os moradores locais e o restante do Império, e das guerras civis que dividiram grupos políticos oposicionistas. Essa tendência bélica estava na personalidade do morador do sul antigamente, quando tinha de ser forte e bravo para enfrentar as intempéries, em vista da tradição econômica do Estado ser a agropecuária.

Em relação ao passado histórico da Irlanda, é importante mencionar a grande fome ocorrida entre os anos 1845 e 1849, representativa de um choque social que entrou para a memória popular. A causa foi uma doença que contaminou as batatas em toda Europa. Estima-se que quase trinta por cento da população irlandesa teria perecido. Para entender a conjuntura política em que se deu essa crise é preciso remontar ao Ato de União de 1800, que governava a Irlanda e a tornava integrante do chamado Reino Unido da GrãBretanha e Irlanda. Vivendo na Inglaterra, os representantes do poder executivo irlandês, que eram os donos das terras e compunham a minoria protestante do país, exploravam suas plantações na Irlanda, pagando miseravelmente aos trabalhadores do campo, e transferindo o lucro para o país onde residiam. As relações difíceis entre os dois países aumentaram em função da continuidade de exportação de alimentos (grãos e gado) para a 
Inglaterra enquanto milhares de pessoas literalmente morriam de fome na Irlanda. A época que precede a escritura de Dublinenses era um turbilhão de mágoa da parte irlandesa católica empobrecida contra o vizinho inglês, protestante e abastado, "pois apenas cinquenta anos haviam passado desde os tempos da fome endêmica" (O'Brien, 2001, p. 36).

Também cabe fazer uma contextualização da vida pessoal dos escritores em relação ao período de escritura das obras estudadas neste trabalho. Contos Gauchescos foi publicado quando Lopes Neto tinha 47 anos. Ele havia morado no Rio de Janeiro durante a adolescência e parte da vida adulta, enquanto era estudante de Medicina. Seu contato com a vida campeira ocorreu somente até os 13 anos. Quando escreve sobre os "causos" de ambientação rural, Lopes Neto estava afastado desse cenário há mais de três décadas. Sua análise crítica do gaúcho campeiro foi redigida com a maturidade de quem conhecia bem a realidade narrada, mas que também conhecia cenários diversos. Quando critica o abandono do sul do Brasil pela monarquia portuguesa no século XIX, em Contrabandista, por exemplo, o escritor fala do monopólio de comércio de certos produtos e da sobretaxa de impostos em outros. Filho e neto de estancieiros que haviam sido comerciantes de charque, Simões conhecia bem o assunto e o drama pelo qual o Rio Grande passara nesse sentido. Amadurecido, o que Simões narra ao longo dos dezenove contos é mais um relato de costumes e a reprodução de "causos de galpão" do que uma crítica contundente.

James Joyce, assim como Simões, estava afastado de sua terra natal ao escrever os contos. O escritor teria saído da Irlanda aos 21, dirigindo-se à França também com o intuito de estudar Medicina e, como o contista gaúcho, acabou não concluindo o curso. O escritor irlandês, porém, estava longe da Irlanda há pouco tempo. Quando escreve Dublinenses, seu posicionamento é influenciado pelo sentimento de desgosto quanto ao que lhe desagradava naquele ambiente: era uma crítica quanto à paralisação em que viviam os indivíduos na Irlanda e esse sentimento o acompanhou por toda vida.

A presença do lugar onde nasceram é constante para ambos os escritores, não só nos livros analisados neste trabalho, como também no conjunto de suas obras. Lopes Neto conseguiu um efeito de interligação entre seus contos a partir da utilização de Blau Nunes, que aparece como narrador |62 Revista Eletrônica Literatura e Autoritarismo, no 26 - julho a dezembro de 2015 - ISSN 1679-849X http://cascavel.ufsm.br/revistas/ojs-2.2.2/index.php/LA/index 
e/ou personagem ao longo do livro e "costura" todos as histórias. É como se fosse um livro sobre rememorações do velho Blau, que lembra episódios vivenciados por ele na juventude e outros que teria escutado dos protagonistas. A narrativa se dá como em uma conversa com um interlocutor, que pode ser o próprio leitor.

Joyce, por sua vez, organiza os contos de Dublinenses representando a ordem cronológica de uma pessoa que passa pela perda da inocência na infância, os dramas e angústias da juventude e caminha em direção a um entendimento com seu "eu" na vida adulta, como as constatações sobre si pelas quais passa o personagem Gabriel, protagonista de Os Mortos. Essa pessoa que amadurece ao longo de Dublinenses é alguém comum, um típico cidadão da capital da Irlanda, mas é também alguém que, mais do que falar sobre uma história de vida individual ou do drama protagonizado em cada conto, personifica um espaço em determinada faixa temporal e fala do declínio econômico e moral de uma cidade subjugada pelas normas do catolicismo.

Lopes Neto e James Joyce tornaram-se conhecidos além das fronteiras do espaço físico que retrataram. A partir de conflitos locais, falaram de dramas universais, cada um a seu modo. A comparatista Tania Carvalhal considerou o diálogo do literário com o conhecimento histórico e reconheceu a pertinência do estudo comparado das diferenças nas investigações acerca de realidades sociais:

...o estudo comparado de literatura deixa de resumir-se em paralelismos binários movidos somente por "um ar de parecença" entre elementos, mas compara com a finalidade de interpretar questões mais gerais das quais as obras ou procedimentos literários são manifestações concretas. Daí a necessidade de articular a investigação comparativista com o social, o político, o cultural, em suma, com a História num sentido abrangente (CARVALHAL, 1992, p. 86).

A literatura comparada parte

da premissa de que as identidades nacionais/ textuais são forjadas em espaços caracterizados por apropriações, sobreposições, transformações e transculturações, o que faz das fronteiras uma linha móvel e permeável aos influxos que procedem de outros lugares, de outras tradições. Nesses termos, poderia se dizer que o reconhecimento daquilo que nos é alheio permite identificar aquilo que nos é próprio (SCHMIDT, 2007, p. 28). 
Diante da complexidade da contemporaneidade, em que culturas diferentes entram em choque e outras permanecem marginalizadas, Rosani Umbach e Vera Lucia Lenz Vianna salientam que confrontar

obras produzidas em espaços geopolíticos distantes e marcados pelo traço da heterogeneidade confere aos estudos comparados um exercício de reflexão intelectual e cultural de amplo alcance, que quebra a linearidade do pensamento, incentiva a compreensão concreta de alteridade e abre caminho rumo à autonomia crítica do leitor (UMBACH e VIANNA, 2009, p. 167).

Através de sua proposta humanizadora, o comparatismo seria uma forma "diferenciada de reteorizar e pensar a humanidade em termos globais e relacionais; um movimento que visa a aproximar a margem do centro, o desconhecido do familiar" (Umbach e Vianna, 2009, p. 167).

Voltando-nos à diferença de abordagem da violência nas obras, podemos citar os contos $O$ negro Bonifácio, de Contos gauchescos, e A casa de pensão, de Dublinenses. O primeiro mostra a banalidade da violência nas relações sociais do gaúcho, em meados do século XIX. Preterido pela amante, Bonifácio inicia uma briga e "contamina" outros presentes na festa que tinham "contas a acertar" com o protagonista. Já no início do conto, sabemos que ele se destacava pela valentia: "... Se o negro era maleva? Cruz! Era um condenado!... mas, taura, isso era, também!" (Lopes Neto, 2001, p. 24). Em um instante e sem nenhuma justificativa, arma-se um cenário de guerra. Até a água que estava fervendo para o chimarrão serviu como arma. $O$ narrador aponta a "belicosidade" de Bonifácio positivamente, como mostra de virilidade e coragem.

Fechou o salseiro. O Nadico mandou a adaga e atravessou a pelanca do pescoço do negro, roçando na veia artéria; o major tocou-lhe fogo, de pistola, indo a bala, de refilão, lanhar-lhe uma perna... o ventana quadrava o corpo, e rebatia os talhos e pontaços que lhe meneavam sem pena (LOPES NETO, 2001, p. 28-29).

O fragmento acima mostra a utilização do linguajar típico sul-riograndense em meados do século XIX e descreve uma cena de violência extrema em ambiente público. Na sociedade apresentada nos contos de Joyce, a violência estaria intimamente relacionada à opressão social e moral atribuída a dois fatores: a influência da igreja católica na sociedade e o alcoolismo. Em $A$ 
casa de pensão, estão presentes o peso das convenções sociais e a influência da religiosidade. Antes de tirar a limpo o assunto da honra da filha com 0 pensionista Doran, a Sra. Mooney pensa que ainda terá tempo de ir à missa do meio-dia e sabe que terá "todo o peso da opinião pública a seu lado" (Joyce, 2012, p.60). Nesse conto, a vítima é o Sr. Doran, seduzido pela esperta Polly, que conta com o peso das tradições e o valor dos costumes para garantir o arranjo de um casamento. Ainda que não fosse uma pessoa ingênua, ele se vê enredado pela "moral e bons costumes". A Sra. Mooney se refere à conversa que terá com o futuro genro como a uma batalha de cuja vitória está certa. A frase "Tinha certeza de que venceria" se repete ao longo do conto. Doran, em contrapartida, está derrotado. Enquanto tenta barbear-se lembra da confissão ao padre na noite anterior e a sensação de culpa era tamanha que ele quase agradece "a chance de poder reparar a falta" (Joyce, 2012, p. 61), ou seja, casar. O fragmento demonstra uma alusão do narrador à manutenção das convenções sociais como se fossem obrigações ou castigos. 0 convencionalismo das tradições oprime as personagens em Dublinenses.

O peso das convenções sociais sobre os cidadãos da capital irlandesa também pode ser observado no conto Eveline. A protagonista, cansada da vida monótona, depara-se com a possibilidade de mudança, de viver um romance em país estrangeiro e construir seu lar, mas está presa à promessa feita à mãe de cuidar da casa depois de sua morte e constata que o pai, envelhecido, embora nem sempre fosse um bom pai, sentiria sua falta. Enquanto se prepara para deixar a casa e ir ao encontro de Frank pegar o barco noturno que os levaria a Buenos Aires, tem uma lembrança triste da vida de sacrifícios cotidianos que levou a mãe à loucura e teme que esse fosse também o seu fim. Impulsionada por esses pensamentos, vai ao encontro do namorado, com quem seu vínculo era estabelecido mais pela esperança de mudança e de fuga do que por laços de afeto. Mas falta-lhe coragem de romper a zona de conforto da vida cotidiana e recorre a uma oração para tomar uma decisão acertada. "Sentiu o rosto pálido e frio e, em um labirinto de sofrimento, rezou a Deus para que a guiasse, para que indicasse o caminho do dever" (Joyce, 2012, p.36). A lembrança da religião, o voltar-se para sua fé, faz com que a dúvida sobre se deveria partir aumentasse e Eveline abandona sua chance de mudança. $O$ caminho do dever "indicado" pela oração foi o da renúncia. A jovem fica 
paralisada, sem conseguir esboçar ao namorado que a chama nem mesmo um olhar de despedida. Ela se sente física e moralmente impedida de avançar para o futuro desejado.

Ainda no mesmo conto temos referência à memória que parecia submersa, mas que vem à tona em um momento decisivo da vida da protagonista: suas últimas horas na casa onde crescera. Enquanto criava coragem para sair, ouvira ao longe o som de um realejo. E lembrou imediatamente da melodia de um outro realejo na última noite da mãe, o que a levou a lembrar da promessa feita em seu leito de morte, de que tomaria conta da casa e da família. "Ela reconheceu a melodia. Estranho que surgisse justo naquela noite para lembrá-la da promessa feita à mãe, a promessa de cuidar da casa enquanto pudesse" (Joyce, 2012, p. 35).

Em conferência proferida no Brasil, em 1987, o teórico austríaco Michael Pollak atenta para o caráter flutuante da memória em função do momento em que ela é articulada, em que está sendo expressa. "Nem tudo fica gravado. Nem tudo fica registrado. [...] As preocupações do momento constituem um elemento de estruturação da memória" (1992, p.203). Essa seletividade da memória faz com que Eveline, na iminência da ruptura definitiva com o contexto que lhe é familiar, enfatize a boa convivência com o pai, apesar de saber que não era esse o lado predominante em sua personalidade. Ela não gostava da maneira como era tratada pela família e no trabalho em sua cidade, e tinha esperança de que longe, onde seria uma senhora casada, a sociedade a respeitasse como indivíduo. No emprego, a chefe "sempre perdia a paciência com ela, em especial quando havia outras pessoas escutando" (Joyce, 2012, p. 33).

Mas na nova casa, em um país distante e desconhecido, não seria assim. Lá ela estaria casada - ela, Eveline. As pessoas haveriam de tratá-la com respeito. Não seria tratada como a mãe havia sido. Mesmo agora, com mais de dezenove anos, às vezes sentia-se vulnerável à violência do pai. [...] Quando estavam crescendo o pai nunca tinha batido nela como fazia com Harry e Ernest porque era uma garota; mas nos últimos tempos havia começado a fazer ameaças (JOYCE, 2012, p.33).

A esse respeito, Pollak pondera que 
...há uma ligação fenomenológica muito estreita entre a memória e o sentimento de identidade. [...] Isto é, a imagem que uma pessoa adquire ao longo da vida referente a ela própria, a imagem que ela constrói e apresenta aos outros e a si própria, para acreditar na sua própria representação, mas também para ser percebida da maneira como quer ser percebida pelos outros (POLLAK, 1992, p. 204).

Outro conto que alude à capacidade de estruturação da memória e o que a faz trazer à tona certas recordações em momentos determinados é Os Mortos, que encerra Dublinenses. Nele, Gabriel e sua esposa têm suas recordações emergindo quase que simultaneamente na saída de uma festa de Natal. A constatação por parte do protagonista de que as memórias do casal não coincidem o enche de ciúme e vergonha. Ele reviu claramente momentos íntimos com ela e recordara as palavras exatas em uma carta que escrevera anos atrás. Essa memória foi ativada por vê-la graciosamente parada junto ao corrimão da escada escutando uma canção que alguém cantava no andar de cima. Ela, ao ouvir a música, remeteu-se à adolescência e se lembrou de um amor do passado, já falecido. "Enquanto sentia-se repleto de memórias da vida secreta do casal, cheio de ternura e alegria e desejo, ela o comparava com outro. Sentiu-se invadido por uma consciência vergonhosa em relação a si próprio" (Joyce, 2012, p. 212). Gabriel vivencia então seu momento de epifania, a partir do qual passa a enxergar a esposa com outros olhos, reflete sobre a própria existência e sobre o fim para o qual todos, inevitavelmente, caminham. "Gabriel refletiu sobre o turbilhão de emoções de uma hora atrás. [...] A própria identidade de Gabriel esvanecia-se em um mundo cinzento e impalpável: o mundo sólido em que aqueles mortos outrora tinham vivido começava a se dissolver e a desaparecer" (Joyce, 2012, p. 215).

Em Contos Gauchescos, é a partir da memória do narrador/personagem Blau Nunes que todas as narrativas se desenvolvem. Essa foi uma estratégia de Lopes Neto para resgatar a figura do contador de "causos", tradicional na cultura gaúcha. "Mais do que um simples narrador, Blau tem a função de dar unidade à obra. Ele é que virá 'costurar' a narrativa" (Lopes Neto, 2001, p. 7 ) a partir da invocação de sua memória pessoal e do que lhe contaram.

${ }^{2}$ Do prefácio "Simões Lopes Neto - Vida e obra", de Everson Pereira da Silva. 
Uma semelhança entre as sociedades da época nos locais representados nessas obras, aos olhos de seus respectivos narradores, é a aversão a tudo que é estrangeiro. Em Partes complementares, de Joyce, o protagonista aumenta a animosidade do chefe para com ele após ter sido pego imitando seu sotaque do norte do país. Em uma noitada com amigos, em um pub, mede forças em um jogo de queda de braço e perde para um jovem estrangeiro considerado pelo protagonista um "parasita". Não é especificado pelo narrador de onde o garoto é, mas sabe-se que não é irlandês.

Nos contos de Lopes Neto, a aversão ao que não é local é apresentada, por exemplo, em Melancia-Coco Verde e Deve um queijo. No primeiro, o narrador sugere que o forasteiro não compartilharia da bravura dos gaúchos e seria arredio aos seus hábitos, como a facilidade em lidar com cavalos e a alimentação baseada em carne vermelha: "Esse tal era um ilhéu, mui comedor de verduras, e que para montar a cavalo havia de ser em petiço e isso mesmo o petiço havia de ser podre de manso..." (Lopes Neto, 2001, p. 91). Já no segundo, quem provoca uma situação de conflito em uma "venda" de beira de estrada é um castelhano, que exige de um recém-chegado que pague um queijo: "Antes que o cumprimentado falasse, o castelhano intrometeu-se: -Ah, és usted de Canguçu?... Entonces... Debe um queso!..." (Lopes Neto, 2001, p. 53). E foi então que o gaúcho cobrado pagou a iguaria e fez com que o castelhano comesse todo o queijo, não sem antes deflagrar-lhe uma surra de facão:

No mesmo soflagrante, de plancha, duro e chato, o velho Lessa derrubou-lhe o facão entre as orelhas, pelas costelas, pelas paletas, pela barriga, pelas ventas... seguido e miúdo, como quem empapa d'água um couro lanudo. E com essa sumanta levou-o sobre o mesmo surrão de erva, pôs-lhe nos joelhos o prato com o resto do queijo e gritou-lhe nos ouvidos: Come!... (LOPES NETO, 2001, p. 55).

Nessa aproximação entre Contos Gauchescos e Dublinenses o que prevalece são as diferenças, como as ocorrências de violência. Nos contos do escritor gaúcho, a violência irrompe com facilidade, faz parte do cotidiano dos personagens e é física, enquanto nos contos sobre a capital da Irlanda o que ocorre é uma violência predominantemente de ordem psicológica, verificada na sensação de estagnação e aprisionamento moral em que se encontram os dublinenses. Mas, se a violência era mais explícita no livro de contos clássico |68| Revista Eletrônica Literatura e Autoritarismo, no 26 - julho a dezembro de 2015 - ISSN 1679-849X http://cascavel.ufsm.br/revistas/ojs-2.2.2/index.php/LA/index 
da cultura gaúcha, quando analisamos a influência da religiosidade na sociedade é nos contos sobre a capital irlandesa que ela prevalece.

Pode parecer estranho, hoje, pensarmos no peso da doutrina católica na estruturação social de uma capital europeia, mas tratando-se de um país de tradição católica intensa e da época na qual se passam os contos, meados do século XIX, mesmo sendo Dublin uma cidade de agitada vida social e predominantemente urbana, os preceitos da igreja ainda falavam muito alto, como falariam ainda por bastante tempo. Mesmo nos dias atuais, quando questões religiosas já não estão atreladas a ações políticas e a cidade está aberta para outros credos, ainda chama a atenção o número de igrejas, capelas e catedrais católicas, com atividades intensas.

A respeito do catolicismo opressor e do alcoolismo, Graça, penúltimo conto de Dublinenses, permite uma observação interessante. Kernan, o protagonista, é um alcoólatra e a trama gira em torno do plano de seus amigos e esposa para convencê-lo a participar de um retiro espiritual que deveria colocá-lo "na linha". O texto traz uma crítica à visão preconceituosa dos irlandeses católicos em relação aos protestantes, invoca a superioridade do catolicismo e do braço irlandês da igreja católica, sugere que a prática da religião constituía mais uma convenção social do que um ato de fé, e mostra que o alcoolismo era um problema em diferentes extratos sociais, atingindo não somente homens como também mulheres.

O Sr. Kernan vinha de uma família protestante e, embora tivesse se convertido ao catolicismo na época do casamento, não havia chegado nem perto de uma igreja nos últimos vinte anos. Além do mais, gostava de dar uns cutucões no catolicismo.

[...] A vida doméstica do Sr. Cunningham não era muito feliz. As pessoas solidarizavam-se porque sabiam que tinha desposado uma mulher inapresentável que era uma bêbada contumaz. Por seis vezes havia mobiliado a casa; e em todas elas a mobília foi penhorada pela esposa (JOYCE, 2012, p. 150-151).

A presença da bebida alcoólica alinhava as relações sociais, mesmo na casa de Kernan, apesar da reprovação do hábito por sua esposa. É ela quem serve garrafas de stout ${ }^{3}$ para os visitantes, que as distribuem "em clima de alegria geral" (Joyce, 2012, p. 155). Quando chega mais um visitante para a

${ }^{3}$ Cerveja escura e forte.

Revista Eletrônica Literatura e Autoritarismo: Narrativas do rastro - ISSN 1679-849X http://cascavel.ufsm.br/revistas/ojs-2.2.2/index.php/LA/index 
reunião, ele traz um presente ao convalescente do "incidente alcoólico": um quarto de litro de uísque especial, que é extremamente apreciado por Kernan: "Eu sabia que podia contar com você, meu velho. Jack, pode abrir a garrafa, por favor?" (Joyce, 2012, p. 160).

A sra. Kernan não alimentava grandes ilusões de uma mudança repentina na conduta do marido. Tinha na religião um hábito, suas crenças não eram extravagantes e sua fé era "limitada pela cozinha", ou seja, pela rotina. "Mas o Sr. Cunningham era um homem hábil; e religião era religião. [...] Ela acreditava que o Sagrado Coração era a mais útil dentre todas as devoções católicas e via os sacramentos com simpatia" (idem, p. 151). O trecho mostra que a religiosidade dos irlandeses estava arraigada a um hábito herdado geração após geração, não era necessariamente algo que os tocasse profundamente o coração, mas antes o cumprimento de um protocolo social que testemunhava bom caráter.

Indagado sobre com quem estava na noite em que sofrera um acidente e machucara a língua (o que o deixara convalescente durante a visita dos amigos que o convenceriam a participar do retiro religioso), Kernan lembra de ter estado com Harford, um cidadão reprovado moralmente pelo grupo por seu hábito de frequentar tavernas, pelo passado como agiota e, claro, pelo fato de não ser católico, mas judeu.

...tinha começado a vida como um agiota obscuro que
emprestava pequenas somas monetárias a juros de usura para
os operários. [...] Embora nunca tivesse abraçado mais do que
o código ético do judaísmo, os colegas católicos que sofriam
extorsão, fosse em pessoa ou por tabela, chamavam-no com
amargura de judeu irlandês analfabeto e viam a reprovação
divina à usura manifesta na pessoa do filho retardado (JOYCE,
2012, p. 153).

O fragmento dá pistas dá economia enfraquecida pela qual passava a Irlanda do final do século XIX, em que os cidadãos precisavam recorrer a dinheiro a juros, ou para saldar suas dívidas, ou porque enfrentavam dificuldades financeiras em consequência do vício, que os levava à derrocada social. A situação de empobrecimento da sociedade local, refletida na menor valorização das artes, é indicada também na apresentação de um dos amigos visitantes de Kernan, o Sr. M'Coy, a quem o narrador se refere com ironia: 
Em outras épocas o Sr. M'Coy tinha sido um tenor de fama considerável. A esposa, que era soprano, ainda dava aulas de piano para crianças em troca de uma modesta remuneração. $O$ caminho que havia trilhado na vida não era a distância mais curta entre dois pontos, e em certos momentos fora levado a viver da própria astúcia (JOYCE, 2012, p. 152).

Em seguida, a conversa dos amigos tece opiniões sobre a ordem dos jesuítas, sobre a qual Joyce possuía bastante conhecimento dos tempos de colegial. O apreço pela divisão católica é manifestado pelo narrador a partir da fala de Cunningham: "Todas as demais ordens da Igreja em algum momento precisaram ser reformadas, mas a Ordem dos Jesuítas nunca sofreu reforma nenhuma. Nunca desviou do caminho" (Joyce, 2012, p. 157). Mas, logo a seguir, M'Coy sugere que esses religiosos estavam isentos de precisar rever sua conduta porque serviram sempre à burguesia e, sendo assim, nunca foram solicitados a realizar mudanças: "Os jesuítas servem às classes privilegiadas" (Joyce, 2012, p. 157).

O narrador alude a possibilidade de equivalência entre os credos. Enquanto relutava em aceitar o convite para unir-se aos amigos no retiro, Kernan lembra a fala de um amigo protestante que o havia acompanhado a um sermão católico, certa vez: “... me lembro muito bem das palavras dele. Kernan, ele disse, nós fazemos o culto em altares diferentes, ele disse, mas a nossa crença é a mesma. Achei que foi muito bem dito" (Joyce, 2012, p. 159). Os amigos que estão no quarto concordam com o comentário, mas a constatação, a clareza de discernimento em relação à profundidade da fé independente do credo, parte daquele que é protestante. O conto mostra o preconceito que pairava na Irlanda contra aqueles que não abraçavam a fé católica e dá pistas de que essa mesma fé influenciava seus seguidores a serem pouco tolerantes, hipócritas e closed-mind. E a discussão encerra-se com a "carolice" de um católico reivindicando suposta superioridade para o catolicismo: "Mesmo assim, disse o Sr. Cunningham com voz baixa e de maneira eficaz, a nossa religião é $a^{4}$ religião, a fé antiga e original" (Joyce, 2012, p. 159).

Em Contos Gauchescos, a religiosidade se dá como uma aproximação ao mundo espiritual, que acontece não só por intermédio da fé católica, mas

${ }^{4}$ Grifo do autor.

Revista Eletrônica Literatura e Autoritarismo: Narrativas do rastro - ISSN 1679-849X http://cascavel.ufsm.br/revistas/ojs-2.2.2/index.php/LA/index 
também a partir da crença em superstições. O entrelaçamento de credos é aspecto recorrente e presente na cultura sul-rio-grandense do período narrado, e pode ser observado em No Manantial, onde cresce uma roseira, mas que "gente vivente não apanha as flores porque quem plantou a roseira foi um defunto... e era até agouro um cristão enfeitar-se com uma rosa daquelas" (Lopes Neto, 2001, p.33), ou quando "a Maria Altina achou no quarto... uma borboleta preta, das grandes, que ninguém tinha visto entrar" (Lopes Neto, 2001, p. 37) e anunciava tragédia. E também em Os cabelos da china, conto que narra como Blau acabou ganhando um "buçalete e cabresto" (Lopes Neto, 2001, p. 74) feito dos cabelos de uma moça, e que quando soube de sua morte, anos mais tarde, tratou de jogar o amuleto na cova da defunta, que seria de mau agouro ficar com aquele "pedaço" de uma pessoa morta. Em $O$ "Menininho" do presépio, o narrador dá mostras de uma fé inocente nos símbolos católicos e na capacidade desses para a realização de milagres. Diferente da fé como condutora de hábitos e convenções sociais da obra de Joyce, em Contos gauchescos, a fé dos gaúchos estaria associada à simplicidade do povo morador de um ambiente rural. "Quando a ponta do ferro matador estava a uma mão atravessada... a quatro dedos só da carne macia, aí - credo! Louvado seja Deus! - aí rolou da sua caminha de milha... rolou e caiu no boleado do seio da moça, na canhadita dos dois, caiu no regaço da nhã Velinda o Menininho Jesus, como uma defesa..." (Lopes Neto, 2001, p. 152).

Os contos Os cabelos da china e O "Menininho" do presépio apontam para mais uma diferença marcante entre as obras: a questão do narrador, que em Contos Gauchescos, nesas duas histórias e em muitas outras, é em primeira pessoa, tendo em Blau Nunes o narrador e/ou protagonista das tramas e não há investigação psicológica. Em Dublinenses, apenas os três primeiros contos, que se referem à infância e perda da inocência da juventude, As irmãs, Um encontro e Arábia, são narrados em primeira pessoa. Nos demais, o narrador em terceira pessoa oferece análise psicológica mais aprofundada dos protagonistas. Aqui cabem mais uma vez como exemplo os personagens Eveline, Farrington e Gabriel, dos quais o leitor recebe informações quanto ao estado de espírito e personalidade e estão humanizados em narrativas que se assemelham a relatos da vida real. 
Ao aproximar obras de contextos sociais e históricos tão diferentes quanto Contos Gauchescos e Dublinenses, possibilitamos uma leitura contextualizada entre contos inseridos na literatura terceiro-mundista e contos inseridos na literatura do chamado primeiro mundo. Lopes Neto, cuja narrativa está vinculada ao regionalismo de um espaço periférico, teve seu valor reconhecido nacionalmente, mas não atingiu tanta popularidade fora da região em que viveu e retratou em sua obra. Joyce, em contrapartida, ultrapassou as barreiras da região que retratou, foi recebido pela crítica com popularidade dentro de algum tempo e situa-se entre os cânones. Observando o gênero conto e a contemporaneidade da primeira publicação dos títulos, partimos para um cotejo que permite avaliar as diferenças históricas que marcaram os espaços em que as obras se situam e identificar nelas semelhanças de comportamento.

A literatura comparada presta contribuição a uma maior tolerância entre os povos, a partir do entendimento de suas diferenças e peculiaridades. A respeito do caráter diplomático da disciplina, Jeune acredita que "a literatura comparada contribui para dissipar o clima de incompreensão e desentendimento entre os povos. Elimina os mal-entendidos. Adquire uma função política dando à palavra seu sentido mais nobre e mais generoso" (Jeune, In: Carvalhal e Coutinho, 1994, p. 238). O objetivo da constituição da literatura universal seria "agir como fonte de tolerância e entendimento" entre os povos (Heise, 2007, p. 45). Pensando o papel da literatura comparada, Rita Terezinha Schmidt lança o questionamento:

Como lugar de produção de conhecimento, pode se colocar na contracorrente do mercado da informação técnica e da razão instrumentalizada pelo capital e seus processos hegemônicos e excludentes e se aliar aos esforços na busca de conhecimentos que venham concretamente ao encontro das aspirações de uma sociedade mais justa e solidária, na perspectiva de melhores condições de vida no planeta? (SCHMIDT, 2007, p. 27).

A resposta vem pelo conceito ideal de ser humano e pela consciência ética, "princípio que destaca o respeito à liberdade pela qual a autonomia individual é corrigida como virtude pessoal de modo a garantir o direito de um como limite em relação ao direito de um outro" (Schimidt, 2007, p. 27). 
Celeste Sousa destaca que "o espaço estrangeiro pode tornar-se, e isso acontece com frequência, reflexo da representação do que é próprio" (2009, p. 174). O atual fluxo de informações e a globalização proporcionam e tornam "inevitáveis os choques culturais" (Alós e Schmidt, 2009, p. 145) e é papel dos comparatistas auxiliar para que esses choques resultem em saldo positivo "para as coletividades humanas do planeta" (Alós e Schmidt, 2009, p. 145). O comparatismo pode ser prática de resistência aos riscos da homogeneização cultural. Os autores salientam o caráter de alteridade assumido pela literatura comparada:

Os estudos da literatura comparada lidam, antes de tudo, com palavras e com culturas, sejam estas próprias, sejam estas alheias. [...] ... é o trabalho com as palavras e com as culturas o lugar privilegiado para que se possa avançar, construindo, a partir do trabalho intelectual, metáforas conceituais nas quais princípios como a ética, a alteridade, a solidariedade e a tolerância deixem de ser apenas substantivos abstratos, e passem a ser lidos como diretrizes, redimensionando assim as nossas ações no mundo. [...] Dar ouvido às vozes outras [...] configura-se como uma questão urgente e estratégica a colaborar para a construção de uma cidadania global e de uma consciência planetária. (ALÓS e SCHMIDT, 2009, p. 145).

No que tange as obras utilizadas para este estudo, apesar de cada escritor tratar sobre questões particulares a uma região e situarem-se geograficamente distantes, é possível realizar um cotejo entre alguns contos. Considerando as diferenças socioculturais e estilísticas peculiares a cada autor, percebe-se que a tônica de cada narrativa é a representação de sua gente, de um determinado espaço, dos hábitos, das relações interpessoais, dos códigos culturais que interditam e limitam suas ações. Simões concede voz à gente do Rio Grande do Sul, e são os habitantes de Dublin que transitam no universo ficcional de Joyce. A caracterização dos costumes dá espaço às dores e mágoas de personagens que se assemelham a seres reais, humanizados aos olhos do leitor. A violência caracteriza o espaço tanto das personagens simonianas como das joyceanas, e é um aspecto interligado à vida em comunidade ou a eventos históricos traumáticos que assumem uma dimensão fora do controle individual.

Este estudo reiterou o vínculo entre Literatura, Cultura e História. Através do universo literário, tanto escritores como leitores procuram falar e compreender suas experiências, como propõe Ilva Maria Boniatti: "Se literatura 
e história sempre estiveram no quadro das ciências humanas, justapostas e recorrentes, ambas, hoje, com muito mais procedência, assumem essa relação, uma vez que a literatura comparada recupera, na prática, os princípios da historicidade" (Boniatti, 2000, p. 33).

Em Contos Gauchescos e Dublinenses, Simões e Joyce, respectivamente, desnudam uma forma de pensar a sociedade, cada um através de sua subjetividade, oferecendo ao leitor a chance de construir uma rede de sentidos e nexos.

\section{REFERÊNCIAS}

ALÓS, Anselmo Peres e SCHMIDT, Rita Terezinha. Margens da poética/ Poética da Margem: o comparatismo planetário como prática de resistência. Organon, Porto Alegre, n. 47, p. 129-145, 2009.

BONIATTI, Ilva Maria Bertola. Literatura Comparada - Memória e região. Caxias do Sul: EDUCS, 2000.

BELLEI, Sérgio Luiz Prado. Repensando a literatura comparada: Edward Said e Fredric Jameson. Revista de Estudos de Literatura. Belo Horizonte, v. 5, p. 11-38, 1997.

CARVALHAL, Tania Franco. Literatura Comparada. São Paulo: Ática, 1992. Literatura comparada: a estratégia interdisciplinar. Revista Brasileira de Literatura Comparada. n.1, Niterói, p. 921, 1991.

Teorias em literatura comparada. Revista Brasileira de Literatura Comparada. no 2, São Paulo, 2013. p. 9-18.

Intertextualidade: a migração de um conceito. Via Atlântica. São Paulo, nº 9, 2006, p. 125-136.

CARVALHAL, T. F. e COUTINHO, E. (Orgs.). Literatura comparada: textos fundadores. Rio de Janeiro: Rocco, 1994.

GINZBURG, Jaime. Literatura, violência e melancolia. Campinas: Autores Associados, 2012.

HEISE, Eloá. Weltliteratur, um conceito transcultural. Revista Brasileira de Literatura Comparada. n. 11, São Paulo, p. 35-58, 2007. 
JOYCE, James. Dublinenses. Porto Alegre: L\&PM, 2012.

LOPES NETO, João Simões. Contos Gauchescos e Lendas do Sul. Porto Alegre: L\&PM, 2001.

O'BRIEN, Edna. James Joyce. Rio de janeiro: Objetiva, 2001.

POLLAK, Michael. Memória e identidade social. In: Estudos Históricos. Rio de Janeiro. vol. 5, n. 10, 1992, p. 200-212.

SOUSA, Celeste H. M. Robeiro. Literatura e imagologia: uma interação produtiva. Revista de Literatura Comparada. n.17, São Paulo, p. 159-186, 2011.

SCHMIDT, Rita Terezinha. Alteridade planetária: a reinvenção da literatura comparada. Revista Brasileira de Literatura Comparada. Porto Alegre, n. 7, p. 113-130, 2005.

A literatura comparada neste admirável mundo novo. Revista Brasileira de Literatura Comparada. n. 11, São Paulo, p. 11-33, 2007.

UMBACH, Rosani Ketzer e VIANNA, Vera Lucia Lenz. Literatura comparada: uma estética humanística. Caderno de Estudos Culturais: Literatura hoje. n. 2. Campo Grande: Editora UFMS, p. 163-176, 2009. 